\title{
HYDROGENATION AND ITS EFFECT ON CRYSTAL STRUCTURE AND MAGNETISM IN RENiAl INTERMETALLIC COMPOUNDS
}

\author{
A. V. Kolomiets ${ }^{1,2}$, L. Havela ${ }^{1}$, V. A. Yartys ${ }^{2}$, A. V. Andreev ${ }^{1,3}$ \\ ${ }^{1}$ Department of Electron Systems, Charles University, Ke Karlovu 5 , \\ 12116 Prague 2, The Czech Republic, \\ 2 Metal Hydrides Laboratory, Karpenko Physico-Mechanical Institute \\ of the National Academy of Sciences of Ukraine, 5, Naukova Str., 290601 Lviv, Ukraine, \\ ${ }^{3}$ Institute of Physics, Academy of Sciences of the Czech Republic, Na Slovance 2, \\ 18000 Prague 8, The Czech Republic
}

(Received November 11, 1998)

\begin{abstract}
RENiAl ( $R E=\mathrm{Y}, \mathrm{Gd}, \mathrm{Tb}, \mathrm{Dy}, \mathrm{Er}$ and Lu) ternary intermetallic compounds crystallizing in the ZrNiAl-type hexagonal structure absorb up to $1.4 \mathrm{H}$ atom/f.u. at ambient pressure. They form hydrides with magnetic properties notably different from those of parent intermetallics, especially showing much lower ordering temperatures. Modification of the magnetic structures and, for the majority of compounds, orthorhombic distortion of the initial hexagonal symmetry are accompanying hydrogenation (deuteration).
\end{abstract}

Key words: rare earth metals, magnetism, hydrides, deuterides.

PACS numbers: 61.10.Lx, 71.27.+a, 75.30.-m, 75.30.Cr, 75.50.Ee

\section{INTRODUCTION AND MOTIVATION}

Intermetallic compounds based on the regular lanthanide metals display pronounced magnetic properties, based on the well defined $4 f$ magnetic moments interacting via indirect exchange interaction of the RKKY type. As the polarisation of conduction electrons is essential for this type of interaction, the severe variation of conduction-electron concentration due to $\mathrm{H}$-bonding made magnetic properties very sensitive to $H(D)$ content.

Another prominent feature of rare-earth intermetallic compounds is their ability to absorb larger amounts of hydrogen. $\mathrm{LaNi}_{5}$ is the best known example here [1] and it is even commercially used as hydrogen storage media. Aluminium additions to the composition of intermetallic compounds of rare earth and transition metals substantially influence their hydrogen sorption capacity and stability of the hydrides formed. $R E_{3} \mathrm{Ni}_{8} \mathrm{Al}$ [2] and $R E_{3} \mathrm{Ni}_{6} \mathrm{Al}_{2}$ [3] represent examples of such hydrogen absorbers with rather high affinity to hydrogen.

Usually the uptake of larger amounts of hydrogen is accompanied by the expansion of the crystal lattice, sometimes symmetry of original unit cell is modified, as well. The motivation of our research presented in this paper is to study the effect of hydrogenation (deuteration) on magnetic properties of $R E \mathrm{NiAl}$ ( $R E=$ rare-earth atom) equiatomic compounds, that crystallize in the hexagonal structure of the $\mathrm{ZrNiAl}$ type [4].

Hydrogen interaction with RENiAl compounds was studied till now for $R E=\mathrm{Y}, \mathrm{Ce}$ and Gd $[5,6,7]$. YNiAlD $_{1.45}$ was synthesised using gas pressure of 60 bar at room temperature. Hydrogen absorption resulted in an increase of the volume of the unit cell with no changes in its hexagonal symmetry [5]. In GdNiAl the uptake of 1 $\mathrm{H}$ atom/f.u has led to the decrease of ordering temperature from $56 \mathrm{~K}$ to $30 \mathrm{~K}$ [6]. For Ce, hydrogenation drives strongly mixed valent CeNiAl to the trivalent state with Curie-Weiss character of magnetic susceptibility [7].

\section{EXPERIMENTAL DETAILS}

Intermetallic compounds $R E \mathrm{NiAl}$ were prepared by arc melting of constituent metals in stoichiometric proportions. The compounds obtained were characterised by $X$-ray powder diffraction (Philips PW 1012/10 diffractometer with $\mathrm{Cu}-\mathrm{Ka}$ radiation) and found to be single phase materials with the hexagonal crystal structure of the $\mathrm{ZrNiAl}$ type. The values of lattice parameters obtained in this work are in good agreement with the literature data [8].

Hydrogenation (deuteration) was performed at hydrogen pressure of 1 bar. Initially the samples were activated in vacuo $(1 \mathrm{~Pa})$ at $300^{\circ} \mathrm{C}$ for 1 hour. In most cases absorption started 5-10 min. after hydrogen admission into the reaction chamber. Usually a low absorption rate was observed and about 70-90\% of hydrogen was absorbed during the first 1-2 hours of interaction. The quantity of absorbed gas was determined by monitoring the pressure drop in the calibrated volume.

Afterwards the structure of materials obtained by hydrogenation was studied using $X$-ray diffraction. These studies confirmed the completeness of hydrogenation since no peaks of the parent $R E \mathrm{NiAl}$ compounds were found in the hydrogenated samples.

Hydrides with lower $\mathrm{H}$ content were obtained by stepby-step deuterium desorption from the saturated hydride in vacuum. Thermal stability was studied by Hydrogen Differential Thermal Analysis (HDTA) method, in which the studied material is decomposed at a constant heating rate (in our case that was $5 \mathrm{~K} / \mathrm{min}$ ) in high dynamic vacuum and the slightest pressure changes are 
monitored. The presence of several peaks on HDTA curve can be interpreted as the presence of several H-evolution effects that correspond either to 1) desorption of hydrogen from different crystallographic positions with different bonding energies or 2) dependence of the metal-H bonding energy on hydrogen content. The details of the techniques used are described in [9].

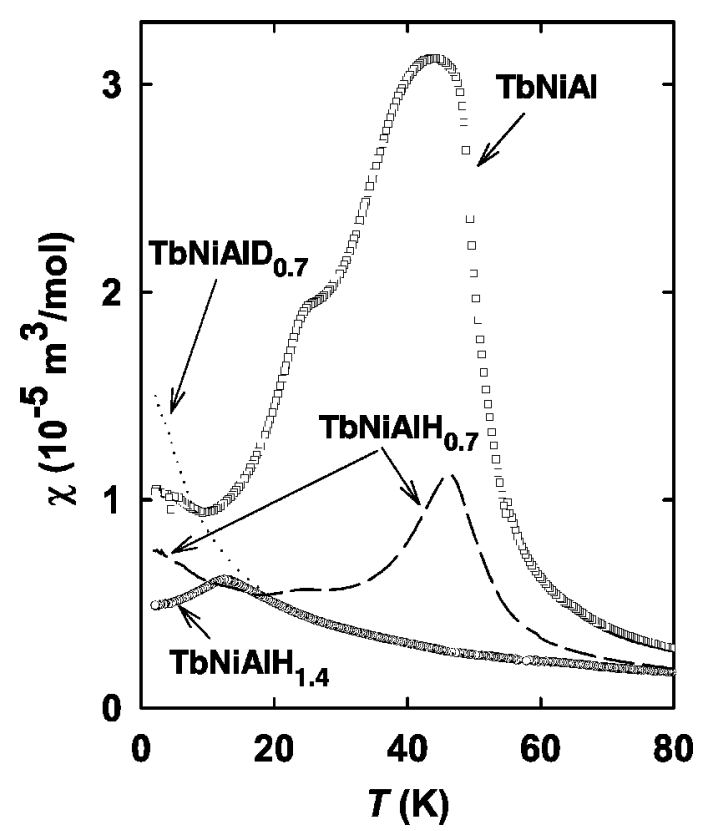

Fig. 1. Temperature dependence of magnetic susceptibility of $\mathrm{TbNiAl}$ and its hydrides and deuteride. All data were obtained in the field $\mu_{0} H=0.1 \mathrm{~T}$ except for the deuteride, where $\mu_{0} H=1 \mathrm{~T}$ was applied.

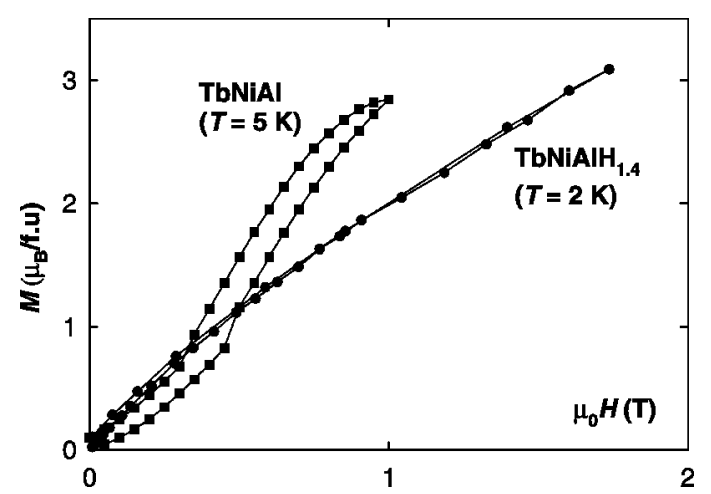

Fig. 2. Field dependence of magnetization of TbNiAl [10] (squares) and its saturated hydride (circles). The lines are eye-guides.

Magnetic properties were studied on randomly oriented powders, fixed by diluted glue, by means of Faraday balance and SQUID techniques. Faraday balance measurements were performed on Oxford Instruments equipment at the temperatures down to $1.8 \mathrm{~K}$ and fields up to $5 \mathrm{~T}$. In several cases the Quantum Design SQUID magnetometer with the temperature range of $1.7-400 \mathrm{~K}$ and the available fields of up to $5 \mathrm{~T}$ was used.

\section{RESULTS}

In the RENiAl intermetallics studied the hydrogenation led to the absorption of 1.0 to $1.4 \mathrm{H}$ atoms/f.u. and to an expansion of the crystal lattice. The volume expansion was on the level of several per cent, reaching the maximum $\Delta V / V=6.6 \%$ for $\mathrm{TbNiAlH}_{1.4}(\Delta V / V-$ relative increase of a unit cell volume). A more detailed information on the modification of the crystal lattice for all an studied materials is presented in Table 1. As can be seen, the deformation of the lattice under hydrogenation is anisotropic. Namely, the unit cell is expanded in the basal plane and contracted along the $c$-axis. Basalplane expansion is anisotropic, too: the $a-$ and $b$-axes of the original hexagonal unit cell are no longer equivalent (illustrated by parameter $\gamma$ in Table 1 ), which leads to an orthorhombic distortion for all saturated hydrides except for $\mathrm{LuNiAlH}_{1.0}$.

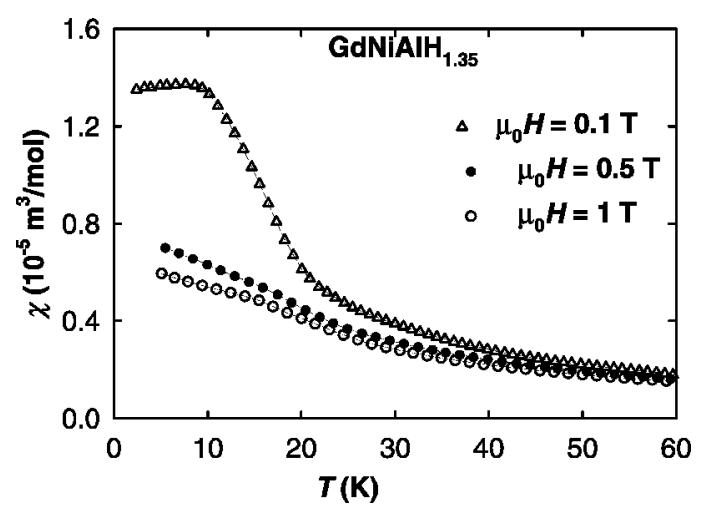

Fig. 3. Magnetic susceptibility of $\mathrm{GdNiAlH}_{1.35}$ measured in various fields in comparison with the data obtained for the GdNiAl intermetallic compound in very low fields (multiplied by the factor of 0.1 to fit in the same scale).

For TbNiAl we have obtained not only the saturated hydride but two intermediate compounds, i.e. $\mathrm{TbNiAlH}_{0.4}$ and $\mathrm{TbNiAlH}_{0.7}\left(\mathrm{TbNiAlD}_{0.7}\right)$, as well. These lower hydrides were obtained during the HDTA study of TbNiAl-H by stopping the desorption after the HDTA spectrum coming through the maximum at $433 \mathrm{~K}\left(\mathrm{TbNiAlH}_{0.7}\right)$, or $483 \mathrm{~K}\left(\mathrm{TbNiAlH}_{0.4}\right)$. Each maximum corresponds presumably to a certain hydrogen crystallographic position with its characteristic bonding energy. Altogether 3 peaks in the HDTA spectrum of TbNiAl-H were observed. The third peak is observed at $593 \mathrm{~K}$, corresponding to the complete decomposition of $\mathrm{TbNiAlH}_{1.4}$. $X$-ray diffraction patterns of the decomposed material confirmed the restoration of the original crystal structure of TbNiAl. 
Magnetic properties of the parent $R E \mathrm{NiAl}$ compounds have been already studied [8,10-13]. Various types of ferromagnetic or antiferromagnetic order were observed. Our experiments have shown that ordering temperatures as well as the type of the magnetic order are strongly affected by hydrogenation [14,15]. The example of TbNiAl-H demonstrates the step-wise character of the variation of the magnetic properties.

The behaviour of $\mathrm{TbNiAlH}_{0.7}$ strongly resembles that of the parent compound TbNiAl (Fig. 1). There are two anomalies, that may be associated with antiferromagnetic ordering, on the temperature dependence of magnetic susceptibility $\chi(T)$ at $T=45 \mathrm{~K}$ and $24 \mathrm{~K}$. These values are very close to the ordering temperatures of pure TbNiAl ( $45 \mathrm{~K}$ and $24 \mathrm{~K}$ ). But the shape of the anomalies is different, and maximum values of the susceptibility are lower for the hydride. Paramagnetic Curie temperatures evaluated from high-temperature parts of $\chi(T)$ are also different. We obtained $\theta_{\mathrm{P}}=25 \mathrm{~K}$ and $8 \mathrm{~K}$ for $\mathrm{TbNiAl}$ and $\mathrm{TbNiAlH}_{0.7}$, respectively, hydrogenation did not affect the value of the effective moment $\mu_{\text {eff }}$, which is $9.40 \mu_{\mathrm{B}} /$ f.u. in both cases. Free ion value of the effective moment is $9.72 \mu_{\mathrm{B}} / \mathrm{Tb}^{3+}$. Also both TbNiAl and $\mathrm{TbNiAlH}_{0.7}$ exhibit a metamagnetic transition below $1 \mathrm{~T}$. All this is suggestive of the similarity of magnetic structures both in lower hydride and TbNiAl in which a complicated magnetic structure with the moments along the $c$-axis was indicated by neutron diffraction [12, 17, 18].

\begin{tabular}{|c|c|c|c|c|c|c|c|c|}
\hline compound/hydride & $a(\AA)$ & $b(\AA)$ & $c(\AA)$ & $\begin{array}{c}\Delta V / V \\
(\%)\end{array}$ & $\begin{array}{c}\Delta a / a \\
(\%)\end{array}$ & $\begin{array}{c}\Delta b / a \sqrt{3}^{(\$)} \\
(\%)\end{array}$ & $\begin{array}{l}\gamma^{(*)} \\
(\%)\end{array}$ & $\begin{array}{l}\Delta c / c \\
(\%)\end{array}$ \\
\hline YNiAl & $7.036(1)$ & - & $3.839(1)$ & - & - & - & - & - \\
\hline YNIAlH $_{1.2}$ & $7.602(4)$ & $12.353(7)$ & $3.713(4)$ & 5.9 & 8.0 & 1.4 & 6.2 & -3.3 \\
\hline GdNiAl & $7.0125(8)$ & - & $3.9140(9)$ & - & - & - & - & - \\
\hline GdNiAlH $_{1.35}$ & $7.636(4)$ & $12.378(1)$ & $3.736(2)$ & 5.9 & 8.9 & 1.9 & 6.4 & -4.5 \\
\hline TbNiAl & $6.999(1)$ & - & $3.879(2)$ & - & - & - & - & - \\
\hline $\mathrm{TbNiAlH}_{0.4}$ & $7.034(1)$ & - & $3.897(1)$ & 1.5 & 0.5 & - & - & 0.5 \\
\hline TbNiAlH $_{1.4}$ (saturated) & $7.636(1)$ & $12.353(2)$ & $3.7209(7)$ & 6.6 & 9.1 & 1.9 & 6.6 & -4.1 \\
\hline $\mathrm{TbNiAlD}_{1.1}^{(\&)}$ & $7.6075(2)$ & $12.4011(3)$ & $3.7209(7)$ & 6.6 & 8.7 & 2.3 & 5.9 & -4.1 \\
\hline TbNiAlD & $7.0493(6)$ & - & $7.7832(7)^{(!)}$ & $2 \times 1.8$ & 0.72 & - & - & 0.51 \\
\hline DyNiAl & $6.9966(9)$ & - & $3.847(1)$ & - & - & - & - & - \\
\hline DyNiAlD $_{1.2}$ & $7.573(3)$ & $12.340(6)$ & $3.718(2)$ & 6.5 & 8.2 & 1.8 & 5.9 & -3.4 \\
\hline ErNiAl & $6.970(2)$ & - & $3.8003(6)$ & - & - & - & - & - \\
\hline ErNIAlH $_{1.4}$ & $7.4804(3)$ & $12.3298(5)$ & $3.6888(2)$ & 6.4 & 7.3 & 2.1 & 4.8 & -2.9 \\
\hline LuNiAl & $6.943(2)$ & - & $3.757(2)$ & - & - & - & - & - \\
\hline LuNiAlH $_{1.0}$ & $7.192(3)$ & - & $3.636(2)$ & 3.8 & 3.6 & - & - & -3.2 \\
\hline
\end{tabular}

Table 1. Crystallographic characteristics of parent RENiAl intermetallic compounds and their hydrides (deuterides).

(\$) $\Delta b / a \sqrt{3}$, where $\Delta b=b-a \sqrt{3}$ and a stands for lattice parameter of parent $R E N i A l$ compound, $b-$ for that in [010] direction of corresponding hydride (deuteride).

(*) $\gamma=(a-b \sqrt{3}) a$, where $a$ and $b$ stand for lattice parameters of hydride (deuteride).

(\&) $[21]$.

(\#) $[16]$.

(!) original unit cell is doubled along [001] direction.

On the other hand, the saturated hydride $\mathrm{TbNiAlH}_{1.4}$ undergoes antiferromagnetic transition at $T_{N}=14 \mathrm{~K}$ (Fig. 1). As one expects antiferromagnetic transition, its temperature is reduced with increasing magnetic field reaching $10 \mathrm{~K}$ at $\mu_{0} H=3 \mathrm{~T}$. The $\chi(T)$ dependence is affected by a small amount of ferromagnetic impurity. After the standard impurity elimination procedure we obtained $\theta_{\mathrm{P}}=-9 \mathrm{~K}$. Most likely the magnetic structure of the saturated hydride is other than in TbNiAl, since there is only one transition in the hydride and its temperature does not correspond to any of the transitions observed in TbNiAl. Furthermore no metamagnetic transitions can be observed at $T=4.2 \mathrm{~K}$ in the fields up to $5 \mathrm{~T}$ (see Fig. 2). Surprisingly no anomalies indi- cating magnetic ordering were observed for $\mathrm{TbNiAlD}_{0.7}$ (Fig. 1). At higher temperatures its susceptibility is almost identical to that of TbNiAl but no maximum occurs at low temperatures. Instead a monotonous increase of $\chi(T)$ persists to the lowest temperature $(T=1.8 \mathrm{~K})$ which we could reach in our experiment. In this region the $\chi$-values become field dependent. Approximation of temperature dependence of the magnetic susceptibility above $8 \mathrm{~K}$ by the Curie-Weiss law gives the effective moment of $9.30 \mu_{\mathrm{B}} /$ f.u. and $\theta_{\mathrm{P}}=-6 \mathrm{~K}$. Field dependence of magnetisation at $2 \mathrm{~K}$ shows no hysteresis and tends to saturation (Fig. 2). Its shape can be well described by the Brillouin function assuming the magnetic moment $\mu=6.5 \mu_{\mathrm{B}} /$ f.u. The free ion value of the ordered 
moment is $9 \mu_{\mathrm{B}} / \mathrm{Tb}^{3+}$.

In the GdNiAl-H system, the hydrogenation also leads to the decrease of the ordering temperature from $T_{\mathrm{C}}=$ $59 \mathrm{~K}$ in GdNiAl to $T_{N}=11 \mathrm{~K} \mathrm{GdNiAlH}_{1.35}$ (Fig. 3). The $\chi(T)$ dependence of $\mathrm{GdNiAlH}_{1.35}$ obeys the CurieWeiss law down to $20 \mathrm{~K}$ where it turns up abruptly and comes through the maximum at $11 \mathrm{~K}$. Increasing magnetic field suppresses the $\chi$-values while smearing out the peak. The analysis of the high-temperature part of $\chi(T)$ leads to $\mu_{\mathrm{eff}}=7.70 \mu_{\mathrm{B}} /$ f.u. (the free ion effective moment is $7.94 \mu_{\mathrm{B}} / \mathrm{Gd}^{3+}$ ) and $\theta_{\mathrm{P}}=-4 \mathrm{~K}$. The field dependence of magnetisation shows no anomalies up to $5 \mathrm{~T}$ but it strongly deviates from the Brillouin law.

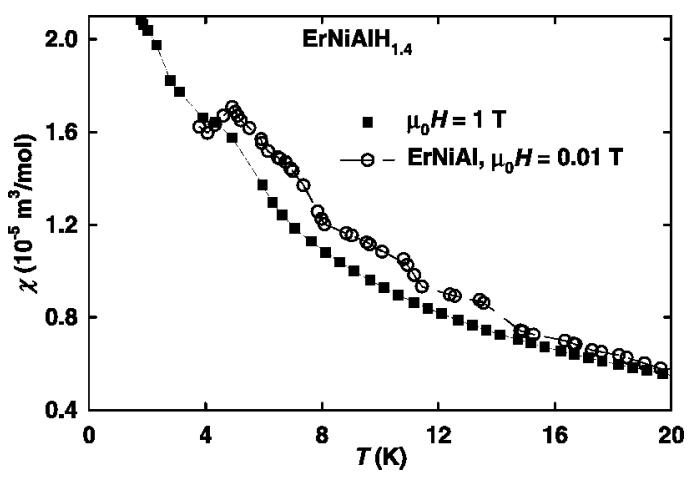

Fig. 4. Magnetic susceptibility of $\mathrm{ErNiAlH}_{1.4}$ compared with the data obtained for ErNiAl.

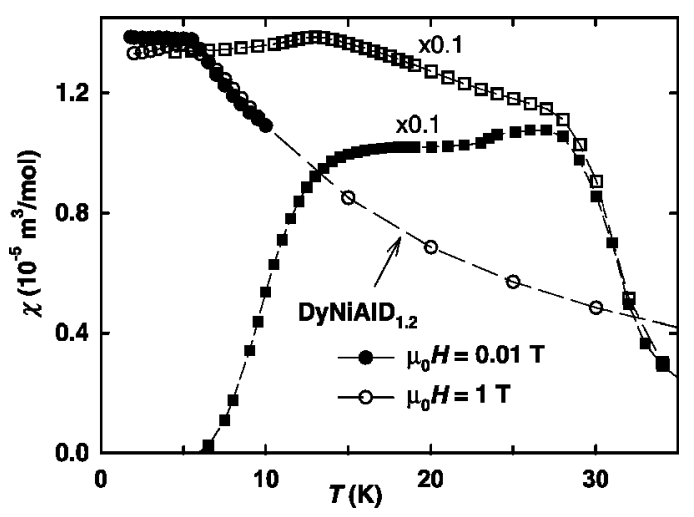

Fig. 5. Magnetic susceptibility of DyNiAlD 1.2 studied in the field of $\mu_{0} H=0.01 \mathrm{~T}$ and $1 \mathrm{~T}$ (circles) compared with the data on DyNiAl obtained in $\mu_{0} H=0.01 \mathrm{~T}$ with zero-field cooling (full squares) and field cooling (empty squares). The latter two curves were adjusted by multiplying by the factor of 0.1 .

No magnetic phase transition was observed in ErNiAlH $_{1.4}$ at least down to $T=2 \mathrm{~K}$ (Fig. 4), while ErNiAl becomes antiferromagnetically ordered at about $5 \mathrm{~K}$ [2]. The analysis of $\chi(T)$ gives $\mu_{\mathrm{eff}}=9.30 \mu_{\mathrm{B}} / \mathrm{f}$.u. (or $9.59 \mu_{\mathrm{B}} / \mathrm{Er}^{3+}$ for free ion) and $\theta_{\mathrm{P}}=-4 \mathrm{~K}$. Magneti- sation of ErNiAlH ${ }_{1.4}$ follows the Brillouin function with $\mu=7 \mu_{\mathrm{B}} /$ f.u. compared to $9 \mu_{\mathrm{B}} / \mathrm{Er}^{3+}$.

DyNiAlD $_{1.2}$ shows paramagnetic behaviour (Fig. 5) down to $T_{N}=5 \mathrm{~K}$ where the maximum in $\chi(T)$ is pointing to antiferromagnetic transition. The analysis of $\chi(T)$ in the paramagnetic range yields $\mu_{\text {eff }}=10.30 \mu_{\mathrm{B}} /$ f.u. (compared to $10.65 \mu_{\mathrm{B}}$ for free $\mathrm{Dy}^{3+}$ ion) and $\theta_{\mathrm{P}}=-8 \mathrm{~K}$. The $M(H)$ dependence taken at $T=4.2 \mathrm{~K}$ shows no hysteresis up to $\mu_{0} H=5 \mathrm{~T}$ and follows the Brillouin function stipulating the magnetic moment of $8-9 \mu_{\mathrm{B}} /$ f.u. (10 $\left.\mu_{\mathrm{B}} / \mathrm{Dy}^{3+}\right)$.

$\mathrm{YNiAlH}_{1.2}$ and $\mathrm{LuNiAlH}_{1.0}$, both containing nonmagnetic rare-earths, exhibit temperature independent susceptibility with the upturn at low temperatures. The presence of this upturn may be explained as a result of the presence of magnetic rare-earth impurities on the level of 0.02 at\%. The hydrogen uptake yields the reduction of susceptibility down to $\chi_{0} \approx 10^{-11} \mathrm{~m}^{3} / \mathrm{mol}$ and $\chi_{0} \approx 10^{-13} \mathrm{~m}^{3} / \mathrm{mol}$, respectively.

\section{DISCUSSION}

The comparison of the magnetic properties of $R E \mathrm{NiAl}$ intermetallics and their hydrides shows that hydrogenation leads to a remarkable decrease of magnetic ordering temperatures and most likely to modification of their magnetic structure. The latter can be deduced from the fact that hydrides show different types of magnetic phase diagrams compared to the parent intermetallics and also the shape of anomalies on $\chi(T)$ related to the transitions is different. As one can notice, the experimental values of the effective magnetic moments $\mu_{\text {eff }}$ remain unchanged upon hydrogenation within the error of fitting procedure, which means that hydrogen bonding does not affect the $4 f$ states of rare earths. But still they are lower than the free ion values. The difference between the observed and free ion ordered moments, $\mu$, may be ascribed to the crystal field effects, that should be quite pronounced in the system with local moments and lower symmetry.

The strength of exchange interactions given by ordering temperatures is generally strongly reduced. Magnetic ordering temperatures follow approximately the De Gennes scaling in parent intermetallics (i.e. are proportional to $S(S+1)$ ). Thus in some cases when ordering temperatures are low in the parent intermetallics due to small spin moments they are shifted out of the range achievable in our experiment (the case of $\mathrm{ErNiAlH}_{1.4}$ ). This trend can be related to the assumed effect of $\mathrm{H}_{-}$ bonding and formation of a low-lying $s$-band [19] which can lead to the reduction of the density of conduction electron states at the Fermi level $N\left(E_{\mathrm{F}}\right)$. A fingerprint of such reduction can be seen also in the strong depression of the susceptibility in Pauli paramagnets $\mathrm{YNiAl}$ and LuNiAl, which is proportional to $N\left(E_{\mathrm{F}}\right)$. Ni-3d states, that are effectively filled up in $R E \mathrm{NiAl}$ compounds, remain probably ineffective for magnetism in hydrides, too. A natural consequence of the loss of electronic states at $E_{F}$ is suppression of the RKKY interaction, in which the 
spin polarisation of conduction electrons is a vital ingredient.

The point which is less clear is the striking difference between the behaviour of $\mathrm{Tb}$-containing saturated hydride and deuteride at low temperatures. This may be due to the existence of two lower hydrides one of which is non-magnetic [20].

In conclusion we should point out that most of the $R E \mathrm{NiAl}$ compounds form hydrides with $\mathrm{H}$ concentration between 1 and $1.4 \mathrm{H}$ atom per formula unit already at ambient hydrogen pressure.

\section{ACKNOWLEDGMENTS}

This work was supported by the grants of the Grant Agency of the Czech Republic, No. 106/98/0507 and the Grants Agency of Charles University, No. 61/1998 and by the ICF grant UCQ200.
[1] J. H. N. Van Vucht, F. A. Kuijpers, H. C. A. M. Bruning, Philips Res. Rep. 25, 133 (1970).

[2] V. A. Yartys, I. I. Bulyk, Sov. Coord. Chem., 18, 441 (1992); V. A. Yartys, I. I. Bulyk, O. V. Nakonechna, B. P. Tarasov, Fiz.-Khim. Mekh. Mater. 2837 (1992).

[3] V. A. Yartys, V. V. Pavlenko, Sov. J. Coord. Chem. 18, 428 (1992).

[4] A. E. Dwight, M. H. Muller, R. A. Conner Jr., J. W. Downey H. Knott, Trans. Metall. Soc. AIME 242, 2075 (1968).

[5] I. Jacob, Z. Hadari, J. J. Reily, J. Less-Common Metals 103, 123 (1984).

[6] H. Drulis, W. Petrynski, B. Stalinski, J. Less-Common Metals 101, 229 (1984).

[7] B. Bandyopadhyay, K. Ghoshray, A. Ghoshray, N. Chatterjee, Phys. Rev. B 38, 8455 (1988).

[8] H. Oesterreicher, J. Less-Common Metals 30, 225 (1973).

[9] D. Book, I. R. Harris, J. Alloys Comp. 221, 187 (1995).

[10] N. C. Tuan, V. Sechovský, M. Diviš, P. Svoboda, H. Nakotte, F. R. de Boer, N. H. Kim-Ngan, J. Appl. Phys. 73, 5677 (1993); Tuan, PhD Theses (Charles University, Prague, 1992).

[11] P. Javorský, N. C. Tuan, M. Diviš, L. Havela, P. Svoboda, V. Sechovský, G. Hilscher, J. Magn. Magn. Mater., 140-144, 1139 (1995).
[12] H. Maletta, V. Sechovský, J. Alloys Comp. 207-208, 254 (1994).

[13] P. Javorský, P. Burlet, V. Sechovský, R. R. Arons, E. Ressouche, G. Lapertot, Physica B 234-236, 665 (1997).

[14] A. V. Kolomiets, L. Havela, V. A. Yartys, A. V. Andreev, J. Alloys Comp. 253-254, 343 (1997).

[15] A. Kolomiets, L. Havela, A. V. Andreev, V. Sechovsky, V. Yartys, J. Alloys Comp., 262-263, 206 (1997).

[16] B. C. Hauback, L. Pålhaugen, V. A. Yartys, H. Fjellvåg, $\mathrm{K}$. Yvon, presented at the International Conference on Metal Hydrides, China, 1998, to be published in J. Alloys Comp..

[17] G. Ehlers, H. Maletta, J. Phys. B 99, 145 (1996).

[18] P. Javorský, P. Burlet, V. Sechovský, A. V. Andreev, J. Brown, P. Svoboda, J. Magn. Magn. Mater. 166, 133 (1997).

[19] A. C. Switendick, Topics in Applied Physics, edited by G. Alefeld, V. Völkl (Springer, Berlin, 1978), p. 101.

[20] H. N. Bordallo, H. Nakotte, J. Eckert, A. V. Kolomiets, L. Havela, H. Drulis, W. Iwasieczko, J. Appl. Phys. 83, 6986 (1998).

[21] V. A. Yartys, F. Gingl, K. Yvon, L. G. Akselrud, A. V. Kolomiets, L. Havela, T. Vogt, I. R. Harris and B. C. Hauback, J. Alloys Comp. accepted for publication.

\title{
НАВОДНЕННЯ ТА ЙОГО ВПЛИВ НА КРИСТАЛІЧНУ СТРУКТУРУ І МАГНЕТНІ ВЛ АСТИВОСТІ ІНТЕРМЕТАЛІЧНИХ СПОЛУК $R E \mathrm{NiAl}$
}

\author{
О. В. Коломієць ${ }^{1,2}$, Л. Гавела ${ }^{1}$, В. А. Яртись ${ }^{2}$ О. В. Андрєєв ${ }^{1,3}$ \\ ${ }^{1}$ Кафедра електронних систем, Карловий університет, \\ вул. Ке Карлову, 5, 12116 Прага 2, Чеська Республіка \\ ${ }^{2}$ Відділ гідридіє металіб, Фізико-механічний інститут ім. Карпенка НАН Украйни, \\ вул. Наукова, 5, Львів, 290601, Украӥна \\ ${ }^{3}$ Iнститут фізики, Академія наук Чеськой Республіки, \\ вул. На Слованце, 2, 18000 Прага 8, Чесъка Республіка
}

Тернарні інтерметалічні сполуки $R E \mathrm{NiAl}$ ( $R E=\mathrm{Y}, \mathrm{Gd}$, Tb, Dy, Er та Lu) з гексагональною кристалічною структурою типу $\mathrm{ZrNiAl}$ поглинають до 1.4 атома водню на формульну одиницю при тиску порядку 1 атмосфери. За магне тними властивостями утворені гідриди суттєво відрізняються від вихідних інтерметалічних сполук, особливо характерним $є$ значне пониження температур магнетного впорядкування. Окрім цього, наводнення (дейтерування) супроводжується зміною магнетних структур, а також, у більшості сполук, орторомбічним спотворенням вихідної гексагональної симетрії. 